\title{
The Right of a Child to Choose a Citizenship in Accordance with Indonesian Legislation Number 12, 2006 on Indonesian Citizenship
}

\author{
Delila Kania \\ Pancasila and Civics Department \\ Pasundan University \\ Bandung, Indonesia \\ delila@unpas.ac.id
}

\begin{abstract}
The enactment of the Citizenship Law No 12 of 2006 has brought up some different consequences, especially towards the status and legal position of children of an intermarriage. Children are subjects of law who are not yet capable of taking legal actions on their own and therefore have to be represented by their parents or legal guardians who have legal capacity. Children get the right to have dual citizenship until the age of 18 years. The concept of legal capacity in the Citizenship Law is determined when a child is at the age of 18 (eighteen) years old, where he or she is given the freedom to choose his or her citizenship status. The age is considered the age of consent at which a child can take a stance and be able to understand the consequences of the choice or decision he or she makes. The concept of legal capacity is closely related to the ability of a citizen to be responsible for his or her decision when he or she chooses the legal status of the citizenship. This research is descriptive-qualitative which means a literature review in a form of an analysis of previous research journals relevant to the topic of this research. For that reason, this research uses the approach of juridical normative. It means an approach done or shown to written regulations and other legal materials, meaning an analytical approach to the Legislation No. 12, 2006 on Indonesian Citizenship.
\end{abstract}

Keywords - legal capacity; the right to choose citizenship; age of consent use a comma as a separator

\section{INTRODUCTION}

Citizenship is the most intimate form of relationship between an individual and his or her country that can guarantee that certain individual his or her rights and obligations in the international court of law.

The enactment of the Citizenship Law No 12 of 2006 has brought up some different consequences, especially towards the status and legal position of children of an intermarriage. This regulation provides supports to those children by allowing them to have dual citizenship until the time they have to choose one, unlike in some other countries where children of an intermarriage are not even granted any citizenship [1].

Citizenship is defined as any relationship in a country that incurs the state's obligations to protect individuals that have all of the requirements to become its citizens [2]. Civil rights have significant importance because it is a manifestation of the state's acknowledgement of its citizens' basic rights. Having citizenship gives people a certain legal position in which they are entitled to having rights and obligations in a mutual relationship with their country.

The matter of who can be considered as Indonesian citizens is regulated in the article 4 of the Citizenship Law No. 12,2006 , which clarify [1]

a. Any person who has become Indonesian citizens in accordance with the law and regulations and/or in accordance with the agreement made by Indonesian government and other countries before the Citizenship Law was in effect;

b. A child born of a legitimate marriage of Indonesian father and mother;

c. A child born of a legitimate marriage of an Indonesian father and a foreigner mother;

d. A child born of a legitimate marriage of a foreigner father and an Indonesian mother;

e. A child born of a legitimate marriage of an Indonesian mother and a father who does not have any citizenship or the law of the father's country of origin does not grand citizenship to the children;

f. A child born in the period of 300 (three hundred) days after his or her father passes away, born of a legitimate marriage of an Indonesian father;

g. A child born of an illegitimate marriage of an Indonesian mother;

h. A child born of an illegitimate marriage of a foreigner mother acknowledged by her Indonesian father as his daughter and the acknowledgement is made official before the daughter turns 18 years old or before she gets married;

i. A child born in Indonesian territory whose parents do not have a clear citizenship status at the time the child is born;

j. A newly born child found in Indonesian territory whose parents are unknown; 
k. A child born in Indonesian territory whose parents do not have any citizenship or whose whereabouts are unknown;

1. A child born outside Indonesian territory of Indonesian father and mother in a country that gives the child citizenship in accordance with the country's law;

m. A child of foreigners whose request for citizenship has been granted but the father or the mother pass away before they take an oath as Indonesian citizens.

As creatures who live within laws and regulations, human beings are entitled to their rights and obligations. However, it does not mean that all people understand law or have legal capacity. The people who do not have the authority or the capacity to take legal actions need to be represented by those who do. Based on Article 1330 of the Book of Civil Law, those who are categorized as incapable are the ones who are pardoned. Children belong to the category of people who do not have the capacity to take a legal action. One who has not reached the age of consent is represented by the parents or the legal guardian in doing a legal action. A child who is born of an intermarriage has the possibility of having parents who have different nationalities, hence are subjects to different jurisdictions.

Determining the age of consent is important because it leads to whether or not somebody is legal or has legal capacity to take a legal action.

The matter regarding who can and has the right to be an Indonesian citizen is written in Article 2 of Citizenship Law that states: "Those who become Indonesian citizens are Indonesian nation and people from other nations that are made legal and official as Indonesian citizens."

Moreover, Article 6 clause 1 of Citizenship Law states that: "Regarding the citizenship status of a child aforementioned in Article 4 point c, point d, point h, point 1 , and Article 5, who has dual citizenship, the child when he or she turns 18 (eighteen) or gets married has to choose one citizenship." This law that is effective in Indonesia is independent to the International Law because the International Law gives freedom to each country to regulate their citizen and citizenship.

\section{THEORETICAL}

Children are subjects to law who are not yet capable of taking legal actions on their own and therefore have to be represented by their parents or legal guardians who have legal capacity.

There are three principles in the process of becoming Indonesian citizens, which are (1) ius sanguinis (law of the blood), which means becoming a citizen based on heredity, (2) ius soli (law of the soil), which means becoming a citizen based on the birth place, and (3) naturalization, which means becoming a citizen granted by the state. The Citizenship Law No. 12, 2006 has added two more principles to it, which are the principle of single citizenship and the principle of restricted dual citizenship (after the child turns 18, he or she has to make a decision).

In addition to the principle of ius soli and ius sanguinis, there are two more systems or rules in determining one's citizenship. These are active system and passive system. The definition of an active system is that one has to take certain legal actions actively to become a citizen. While the definition of passive system is a person by itself is considered to be a citizen without doing any particular legal action. The implementation of the two system resulted in the enactment of two legal consequences, namely option rights and repudiation rights. The definition of option rights is the right to choose a citizenship and change citizenship. Option rights apply in active system. On the other hand, the definition of right to repudiation is the right to refuse a citizenship offered by other countries. This means, one still chooses the country of his or her birth. The right to repudiation applies in passive system.

The legal status of citizenship referred to here is the status of a person in relation to his citizenship in a country in accordance with applicable legislation. The concept of the legal status of citizenship refers to the concept of legal relation between the individual and the state, in addition to referring to the existence or recognition of the juridical rights and the inherent obligations, both to the individual and to the country. The legal status of citizenship in a country is normally regulated in the constitution or national legislation of the country. The constitution or national legislation relates to the issue of citizenship status, generally regulating who can be legally qualified as a citizen, and who also does not. Usually, it also regulates those who, because of the legal status of their citizenship acquire the rights and hold the obligations as citizens.

Based on what has been elaborated, the concept of the legal status of citizenship is generally formulated as follows:

1) The legal status of citizenship is a personal identity attached to a person in relation to the matter of his or her citizenship;

2) The legal status of citizenship provides an overview of the state of the legal relationship between an individual with his or her country;

3) The legal status of citizenship refers to the country's responsibility for the status of a person's citizenship.

\section{METHODOLOGY}

This research is descriptive-qualitative, which is a literature review in a form of an analysis of previous research journals relevant to the topic of this research. It includes the process of journals selection from some universities, followed by analysis and synthesis. Finally, the review will be conducted to study 1) the rationale, such as the relation between the state and its citizens, 2) the subjects of the research, meaning citizens of 18 years of age, 3) the objects, which are the citizenship rights, 4) the instrument development that will be developed after doing the filed study 
for data validation, and the methodology. It is then followed by validating it by making a reference by journal comparisons to what other researchers have done. This descriptivequalitative research examines the ideas, meanings, and the ways by which people perceive matters that are the focus of the research. For that reason, this research uses the approach of juridical normative. It means an approach done or shown to written regulations and other legal materials [3], meaning an analytical approach to the Legislation No. 12, 2006 on Indonesian Citizenship.

\section{RESULTS AND DISCUSSION}

For an Indonesian woman who marries a foreigner, her citizenship status automatically goes away and she follows the laws of her husband's country of origin. However, with the existence of Law no. 12 of 2006 on Indonesian Citizenship, an Indonesian woman may not lose her citizen status as long as she submits her petition to the Ministry of Justice and Human Rights, provided she does not have dual citizenship. As for an Indonesian man who is married to a foreigner, he will lose his citizenship according to the law of his wife's country of origin, because the citizenship of the husband follows the citizenship of the wife as a legal consequence of the marriage. In addition, it also regulates the citizenship status of children born of intermarriage. Children are subjects to law who have not been capable to take his own legal actions so that it should be represented by his parents or guardians who have the capacity.

Children get the right to have dual citizenship until the age of 18 years. The provisions are stipulated in Article 4 point c, point d, point h, Article 5 and Article 6 clause (1) of the Citizenship Law.

However, when they are 18 years of age, the child has the right to choose their citizenship, with a requirement that the decision to select the citizenship have to be made within 3 (three) years after the child turns 18 years old or gets married, in accordance with Article 6 paragraph (3) of the Citizenship Law.

What is defined as a child's legal capacity in the Citizenship Law is when a child of an intermarriage has reached the age of 18 (eighteen) years he or she may choose to take the citizenship of his father or mother.

When someone is committing a legal action of any kind, then his age should be taken into consideration. When someone wants to make an identity card, the requirement states that he or she must be at least 17 years old.

Therefore when a child is choosing his or her own citizenship, he or she does it out of consent and is considered mature by law, where he is considered to be able to see what is good and bad, and is aware of the consequences that he or she will be received from his or her choice. follows:
1. The application for citizenship may be filed by the applicant if they meet the following requirements:

a) Have turned 18 (eighteen) years of age or have been married;

b) Upon application to have resided in the territory of the Republic of Indonesia for at least 5 (five) consecutive years or at least 10 (ten) non-consecutive years;

c) Physically and spiritually healthy;

2. Able to speak Indonesian and acknowledge the Foundations of the State of Pancasila and the Constitution of the State of the Republic of Indonesia Year 1945;

3. Have never been sentenced for committing a criminal offense punishable by imprisonment of 1 (one) year or more;

4. If by obtaining Indonesian citizenship they will not have dual citizenship;

5. Are steadily employed and have stable income; and

6. Pay the fee for obtaining citizenship to the State Treasury.

7. Citizenship application is submitted in Indonesia by the applicant written in Indonesian and legally stamped, addressed to the president through the minister and should at least contain:

a. Full name;

b. Place and date of birth;

c. Gender;

d. Marital status;

e. Address of residence;

f. Occupation; and

g. Nationality of origin.

8. The application on point 2, complete with the requirements is submitted to the official whose working area covers the residence of the applicant;

9. The authorized officer conducts an examination of the administrative requirements of the application within a maximum of 14 days and comes up with these possible results:

a) The application has met the administrative requirements then the officer forwards the application to the minister within a maximum of 7 days from the date when the substantive inspection is completed.

b) In the event that the application does not meet the requirements, the officer returns it to the applicant within 7 days from the date when the substantive inspection is completed.

10. The Minister shall forward the application as referred to in Article 10 and have the president consider it within 3 months since the application is received;

11. The President grants or rejects the request within 45 days from the date when the application is received from the minister;

12. In the event that the application is granted, the president makes a presidential decree and notifies in writing the applicant, along with a copy to the official within 14 days from the date when the president's decision is issued;

13. The decree is communicated to the official to be forwarded to the applicant and his copy is given to the 
minister, the official and representative of the applicant's country of origin;

14. The official summons the applicant in writing to take the oath swear and declare his or her citizenship within 3 months from the date when the presidential decree is sent to the applicant;

15. The applicant attends the ceremony and takes an oath or a solemn promise before the official, witnessed by 2 people and have the ceremony documented;

16. In the event that the applicant is absent without a valid reason then the presidential decree is cancelled.

\section{CONCLUSION}

The Legislation Number 12, 2006 on Indonesian Citizenship guarantees the citizenship of children of an intermarriage. This provision states that a child of intermarriage has the right to decide or to choose his or her citizenship. The right is granted if he or she meets the requirements after the child turns 18 years old.

Children are subjects to law who have not been capable to take his own legal actions so that it should be represented by his parents or guardians who have the capacity.

Children get the right to have dual citizenship until the age of 18 years. The provisions are stipulated in Article 4 point c, point d, point h, Article 5 and Article 6 clause (1) of the Citizenship Law.
The concept of legal capacity in the Citizenship Law is determined when a child is at the age of 18 (eighteen) years old, where he or she is given the freedom to choose his or her citizenship status. The age is considered the age of consent at which a child can take a stance and be able to understand the consequences of the choice or decision he or she makes. The concept of legal capacity is closely related to the ability of a citizen to be responsible for his or her decision when he or she chooses the legal status of the citizenship.

This fact about the right to choose a citizenship has not been widely known by the people, especially by students. It can be made known through Civics Education subject in junior high schools and senior high school as a complementary material, to the existing ones, such as the principles of citizenship that relates to the rights and obligations of the citizens. By understanding this idea, people are hopefully more aware of their own rights and obligations as Indonesian citizens, especially of those who are born from intermarriages.

\section{REFERENCES}

[1] Undang-Undang nomor 12 tahun 2006 tentang Kewarganegaraan Republik Indonesia.

[2] Suparlan Al Hakim, dkk. .2014. Pendidikan Kewarganegaraan dalam Konteks Indonesia. Malang: Madani.

[3] Waluyo Bambang. 1991. Penelitian Hukum Dalam Praktek. Jakarta: Sinar Grafika. 